\title{
Non Performing Assets in Public Sector Banks: A Cause Analysis
}

\author{
R.V. Naveenan ${ }^{1}$, B. Ravi Kumar ${ }^{2} \&$ B. Vijaya Lakshmi ${ }^{3}$ \\ ${ }^{1}$ Department of Management Studies, Vivekananda Institute of Management, India \\ ${ }^{2}$ Department of MBA-Amrita Sai Institute of Science and Technology, India \\ ${ }^{3}$ Department of Business Management, Sri Pamavati Mahila Visvavidyalayam (Women's University)-Tirupati,India \\ Correspondence: R.V. Naveenan, Department of Management Studies, Vivekananda Institute of Management, India. \\ Email: naveenan.08mba@gmail.com
}

Received: July 19, 2018

Accepted: August 25, 2018

Online Published: September 1, 2018

\begin{abstract}
Lending Funds is considered as the primary function of primary function which provides financial support to various sectors such as agriculture, industry, personal loans etc., but in recent times the banks as taken a cautious stand in lending. The main reason for such an initiative is the mounting issues of non-performing assets (NPAs).A loan asset is considered as non-performing asset when it ceases to generate income for the bank. From 31st March, 2004 NPA was defined as a credit facility in respect of which the interest or installation of principal has remained past due for a specified period of time which was four quarters. NPA in public sector banks is increasing year after year and thus this is becoming a debatable topic. So considering this anglete paper is undertaken to analyze the reasons for advances becoming NPA in Public sector banks and intends to give suitable suggestions to overcome NPA.
\end{abstract}

Keywords: NPAs, NPA Classification, Types of NPA, Causes of NPA.

\section{Introduction}

NPA is defined as an advance where payment of interest or repayment of instalment of principal (in case of term loans) or both remains unpaid for a certain period. In India, the definition of NPAs has changed over time. According to the Narasimham Committee Report (1991), those assets (advances, bills discounted, overdrafts, cash credit etc.) for which the interest remains due for a period of four quarters (180 days) should be considered as NPAs. Subsequently, this period was reduced, and from March 1995 onwards the assets for which the interest has remained unpaid for 90 days were considered as NPAs. An NPA is defined as a loan asset, which has ceased to generate any income for a bank whether in the form of interest or principal repayment

\section{Classification of NPA}

NPA have been classified into following four types:

Standard Assets: A standard asset is a performing asset. Standard assets generate continuous income and repayments as and when they fall due.

Sub-Standard Assets: All those assets (loans and advances) which are considered as non-performing for a period of 12 months.

Doubtful Assets: All those assets which are considered as non-performing for period of more as 12 months.

Loss Assets: All those assets which cannot be recovered.

Causes for Non-Performing Assets

External causes: Natural calamities and climatic conditions, Recession, changes in Government policies changes in economic conditions, Industry related problems, Impact of liberalization on industries, Technical problems. 
Internal causes: Internal defaulters, Faculty projects, Most of the project reports are ground realities, proper linkages, product pricing etc. Some approach for the "heck" of starting adventure, with poor knowledge of product risks, over depended on poorly paid killed workers and technicians, Building up pressure for sanctions, Inept handling by banker's lack of professionalism and appraisal standards, Non-observance of system, procedures and non-insistence of collaterals etc, Lack of post sanction monitoring, unchecked diversions.

\section{Review of Literature}

This section provides an overview of some of the existing literature with regard to the NPA. This literature review helps me to better understanding of both research topics and of the existing gap:

Meeker Larry G. and Gray Laura (1987) evaluate that information. A regression analysis comparing the nonperforming asset statistics with examiner classifications of assets suggests that the non-performing asset information can be a useful aid in analyzing the asset quality of banks, particularly when the information is timely.

Toor N.S. (1994) stated that recovery of non-performing as-sets through the process of compromise by direct talks rather than by the lengthy and costly procedure of litigation. He suggested that by constant monitoring, it is possible to detect, the sticky accounts, the incipient sickness of the early stages itself and an attempt could be made to review the unit and put it backon the road to recovery

S.N. Bidani (2002) argued that non-performing Assets are the smoking gun threatening the very stability of Indian banks. NPAs wreck a banks' profitability both through a loss of interest income and write-off of the principal loan amount itself. This is definitive book which tackles the subject of managing bank NPAs in it ${ }^{\text {ee }}$ entirely, starling right from the stage of their identification till the recovery of dues in such ac-counts.

Paul Purnendu, Bose,Swapan and Dhalla, Rizwan S.(2011) attempted to measure the relative efficiency of Indian PSU banks on overall financial performances. Since, the financial industry in a developing country like India is undergoing through a very dynamic paceof restructuring, it is imperative for a bank to continuously monitor their efficiency on Non-Performing Assets, Capital Risk-Weighted Asset Ratio, Business per Employee, Return on Assetsand Profit per Employee. Here, Non-Performing Assets is a negative financial indicator. To prove empirically, we propose a framework to measure efficiency of Indian public sector banks.

Khedekar Pooja S. (2012) recommends that a strong banking sector is essential for a flourishing economy. Indian banking sector emerged stronger during 2010-11 in the aftermath of global financial meltdown of 2008-10 under the watchful eye of its regulator. The level of NPAs acts as an indicator showing the credit risks \& efficiency of allocation of resource. NPA involves the necessity of provisions, any increase in which bring down the overall profitability of banks. An excessive rise in interest rates over the past 18 months has led to a sharp increase in nonperforming assets. This not only affects the banks but also the economy as a whole. Pooja also deals with understanding the concept of NPA, the causes and overview of different sectors in India.

Selvarajan B. and Vadivalagan, G. (2012) state that non-Performing Assets is not a dilemma facing exclusively the bankers; itis in fact an all pervasive national scourge swaying the entire Indian economy. Non-Performing Asset is a sore throat of the Indian economy as a whole. Non-Performing Assets have affected the profitability, liquidity and competitive functioning of banks and developmental of financial institutions and finally the psychology of the bankers in respect of their disposition towards credit delivery and credit expansion. NPAs do not generate any income for the banks, but at the same time banks are required to make provisions for such NPAs from their current profits. Apart from internal and external complexities, increases in NPAs directly affects banks' profitability sometimes even their existence.

Veerakumar, K. (2012) mentions that the Indian banking sector has been facing serious problems of raising NonPerforming Assets (NPAs). Like a canker worm, NPAs have been eating the banking industries from within, since nationalization of banks in 1969. NPAs have choked off quantum of credit, restriction the recycling of funds and leads to asset-liability mismatches. It also affected profitability, liquidity and solvency position of the Indian banking sector. One of the major reasons for NPAs in the banking sector is the 'Direct Lending System' by the RBI under social banking motto of the Government, under which scheduled commercial banks are required to lend $40 \%$ of their total credit to priority sector. The banks who have advanced to the priority sector and reached the target suffocated on account of raising NPAs, since long. The priority sector NPAs have registered higher growth both in percentage and in absolute terms year after year. The present paper is an attempt to study the priority sector advances by the public, private and foreign bank group-wise, target achieved by them and a comparative study on priority and non-priority sector NPAs over the period of 10 years between 2001-02 and 2010-11.the author also aims to find out the categories of priority sector advances which contribute to the growth of total priority sector NPAs during the period under study.

Murthy, K. V. Bhanu Gupta, Lovleen. (2012) studied the impact of liberalization on the non-performing assets of the four banking segments, namely, public sector, old private sector, new private sector and foreign banks by 
studying the overall trends in NPAs. We have used the Structure- Conduct- Performance (S-C-P) approach that shows the relationship between competition and conduct, concentration and growth in NPAS. Our results show that on an average across the banking industry segments, average non-performing assets in the past 11 years have been declining at the rate of $13 \%$ p.a. compounded growth rate. The old private sector banks' nonperforming assets have reduced at the rate of $11.98 \%$ and that of public sector banks have declined at the rate of $18 \%$ and foreign bank sat $11.4 \%$. Though new private sector banks and the foreign banks seem to be more efficient but their conduct does not show consistency and stability.

Joseph, Mabvure Tendai Edson, Gwangwava (2012) attempted to find out the causes of non-performing loans in Zimbabwe. Loans form a greater portion of the total assets in banks. These assets generate huge interest income for banks which to a large extent determines the financial performance of banks. However, some of these loans usually fall in ton on-performing status and adversely affect the performance of banks. In view of the critical role banks play in an economy, it is essential to identify problems that affect the performance of these institutions. This is because non-performing loans can affect the ability of banks to play their role in the development of the economy. A case study research design of CBZ Bank Limited was employed. Interviews and questionnaires were used to collect data for the study. Their study revealed that external factors are more prevalent in causing non-performing loans in CBZ Bank Limited. The major factors causing nonperforming loans were natural disasters, government policy and the integrity of the borrower.

Debarsh and Sukanya Goyal (2012) emphasized on management of non-performing assets in the perspective of the public sector banks in India under strict asset classification norms, use of latest technological platform based on Core Banking Solution, recovery procedures and other bank specific indicators in the context of stringent regulatory framework of the RBI. Non-performing Asset is an important parameter in the analysis of financial performance of a bank asit results in decreasing margin and higher provisioning requirements for doubtful debts. The reduction of non-per-forming asset is necessary to improve profitability of banks and comply with the capital adequacy norms as per the Basel Accord.3

Kavitha. N (2012), tried to have an assessment of non-performing assets on profitability its magnitude and impact. Credit of total advances was in the form of doubtful assets in the past and has an adverse impact on profitability of all Public Sector Banks affected at very large extent when non-performing assets work with other banking and also affect productivity and efficiency of the banking groups. The study observed that there is increase in advances over the period of the study.

\section{Objectives of the Study}

- To study the concept on Non- Performing Assets and its relevance in the banking sector

- To identify the loan/bank based components that contribute to NPA.

\section{Formulation of Hypothesis}

\section{Hypothesis I:}

"There is a significant difference between the importances of bank based internal components that contribute to NPA.

Hypothesis II:

"There is a significant difference between the importances of bank based external components that contribute to NPA".

\section{Methodology}

In order to achieve the objective of the study an appropriate methodology has been adopted. Research done is descriptive in nature.

\section{Source of Data}

The present study is mainly based on Secondary data. The data is taken from the Ph.D Thesis titled "A Study on Handling Non-Performing Assets with special reference to Public Sector Banks in Kanyakumari District".

\section{Statistical Tools Used}

Friedman Test: The Friedman Test is a non-parametric test. It is used to test for differences between groups when the dependent variable being measured is ordinal. 


\section{Data Analysis \& Interpretation}

Mean and SD of Bank based internal components that contribute to NPA

Table 1. Mean and SD of Bank based internal components that Contribute to NPA

\begin{tabular}{clll}
\hline Sl. No. & \multicolumn{1}{c}{$\begin{array}{c}\text { Importance to the Bank based internal } \\
\text { components that contribute to NPA }\end{array}$} & Mean & Std. Deviation \\
\hline 1 & Improper selection of borrowers & 2.18 & 0.872 \\
\hline 2 & Deficiency in processing & 2.00 & 0.886 \\
\hline 3 & Improper appraisal of assets & 2.10 & 0.834 \\
\hline 4 & Lack of monitoring pre and post sanction of loan & 2.57 & 0.680 \\
\hline 5 & Terms and conditions of credit & 1.59 & 0.494 \\
\hline 6 & Unsecured loans & 2.42 & 0.665 \\
\hline
\end{tabular}

Source: Primary Data

\section{Inference:}

From the above table, Lack of monitoring pre and post sanction of loan has the highest mean followed by Unsecured loans, Improper selection of borrowers, Improper appraisal of assets, Deficiency in processing and Terms and conditions of credit. Highest standard deviation of Deficiency in processing shows low focus on the particular internal components that contribute to NPA.

Mean and SD of bank based external components that contribute to NPA

Table 2. Mean and SD of bank based external components that contribute to NPA

\begin{tabular}{lllll}
\hline Sl. No. Importance to the bank based external Mean & Std. Deviation \\
& components that contribute to NPA
\end{tabular}

\begin{tabular}{cllc}
\hline 1 & Selection of unsuitable and Unviable scheme & 2.12 & 0.832 \\
\hline 2 & Mis-utilization of fund & 2.59 & 0.678 \\
\hline 3 & Insolvency or death of borrower & 1.32 & 0.645 \\
\hline 4 & Low income from project & 2.01 & 0.649 \\
\hline 5 & $\begin{array}{l}\text { Lack of infrastructure, Modern Technology and } \\
\text { marketing facilities }\end{array}$ & 1.33 & 0.493 \\
\hline 6 & Political interference and labor unrest & 2.40 & 0.662 \\
\hline 7 & Willful default due to liberal government policy and & 2.42 & 0.799 \\
\hline 8 & Sluggish legal system & 1.62 & 0.673 \\
\hline 9 & Price escalation of inputs & 1.81 & 0.755 \\
\hline 10 & Power failures & 1.99 & 0.891 \\
\hline
\end{tabular}

Inference:

Source: Questionnaire

From the above table, mis-utilization of fund has the highest mean followed by Willful default due to liberal government policy,Political interference and labor unrest,Selection of unsuitable and Unviable scheme,Low income from project,Power failures,Price escalation of inputs,Sluggish legal system,Lack of infrastructure, Modern Technology and marketing facilities,Insolvency or death of borrower. Highest standard deviation of Power failures shows low focus on the particular external components that contribute to NPA.

\section{HYPOTHESIS I}

Null Hypothesis: There is no significant difference between mean ranks towards Importance to the Bank based internal components that contribute to NPA.

Table 3. Friedman test for significant difference between mean ranks towards Importance to the Bank based internal 
components that contribute to NPA

\begin{tabular}{|c|c|c|c|c|}
\hline Sl. No. & $\begin{array}{l}\text { Importance to the Bank based internal } \\
\text { components that contribute to NPA }\end{array}$ & Mean Rank & $\begin{array}{l}\text { Chi- } \\
\text { Square }\end{array}$ & P value \\
\hline 1 & Improper selection of borrowers & 3.62 & 280.580 & $0.000 * *$ \\
\hline 2 & Deficiency in processing & 3.10 & & \\
\hline 3 & Improper appraisal of assets & 3.36 & & \\
\hline 4 & Lack of monitoring pre and post sanction of loan & 4.71 & & \\
\hline 5 & Terms and conditions of credit & 1.89 & & \\
\hline 6 & Unsecured loans & 4.32 & & \\
\hline
\end{tabular}

Source: Primary Data

** Denotes significance at $1 \%$ level

Inference:

Since $\mathrm{P}$ value is less than 0.01 , the null hypothesis is rejected at 1 per cent level of significance. Hence it is concluded that there is significant difference between mean ranks towards Importance to the Bank based internal components that contribute to NPA. From the table, based on mean rank, Lack of monitoring pre and post sanction of loan (4.71) is the best internal component that contribute to NPA, followed by Unsecured loans (4.32), Improper selection of borrowers (3.62), Improper appraisal of assets (3.36), Deficiency in processing (3.10) and Terms and conditions of credit (1.89).

\section{HYPOTHESIS II}

Null Hypothesis: There is no significant difference between mean ranks towards Importance to the Bank based External components that contribute to NPA.

Table 4. Friedman test for significant difference between mean ranks towards Importance to the Bank based External components that contribute to NPA

\begin{tabular}{|c|c|c|c|c|}
\hline Sl.No. & $\begin{array}{l}\text { Importance to the External components that contribute to } \\
\text { NPA }\end{array}$ & Mean Rank & $\begin{array}{l}\text { Chi- } \\
\text { Souare }\end{array}$ & P value \\
\hline 1 & Selection of unsuitable and Unviable scheme & 6.15 & 547.007 & $0.000 * *$ \\
\hline 2 & Mis-utilization of fund & 8.04 & & \\
\hline 3 & Insolvency or death of borrower & 3.04 & & \\
\hline 4 & Low income from project & 5.75 & & \\
\hline 5 & Lack of infrastructure, Modern Technology and marketing & 2.85 & & \\
\hline 6 & Political interference and labour unrest & 7.47 & & \\
\hline 7 & $\begin{array}{l}\text { Willful default due to liberal government policy and expectation } \\
\text { of debt relief }\end{array}$ & 7.39 & & \\
\hline 8 & Sluggish legal system & 3.95 & & \\
\hline 9 & Price escalation of inputs & 4.78 & & \\
\hline 10 & Power failures & 5.59 & & \\
\hline
\end{tabular}

$$
\begin{gathered}
\text { Source: Primary Data } \\
* * \text { Denotes significance at } 1 \% \text { level }
\end{gathered}
$$

\section{Inference:}

Since $\mathrm{P}$ value is less than 0.01 , the null hypothesis is rejected at 1 per cent level of significance. Hence it is concluded that there is a significant difference between mean ranks towards Importance to the Bank based External components that contribute to NPA

From the table, based on mean rank, Mis-utilization of fund (8.04), Political interference and labour unrest(7.47),Willful default due to liberal government policy and expectation of debt relief(7.39),Selection of unsuitable and Unviable scheme(6.15), Power failures(5.59), Low income from project(5.75), Price escalation of inputs(4.78),Sluggish legal system(3.95),Insolvency or death of borrower(3.04),Lack of infrastructure, Modern Technology and marketing facilities(2.85). 


\section{Findings of the Study}

- From Table 7.1 Bank based internal components that Contribute to NPA are ranked on the basis of the response and mean score calculated. Lack of monitoring pre and post sanction of loan has the highest mean followed by Unsecured loans, Improper selection of borrowers, Improper appraisal of assets, Deficiency in processing and Terms and conditions of credit.

- From Table 7.2, Bank based external components that contribute to NPAare ranked on the basis of the response and mean score calculated.Mis-utilization of fund has the highest mean followed by Willful default due to liberal government policy, Political interference and labor unrest, Selection of unsuitable and Unviable scheme, Low income from project, Power failures, Price escalation of inputs, Sluggish legal system, Lack of infrastructure, Modern Technology and marketing facilities, Insolvency or death of borrower .

- From Table 7.3, By Friedman Test it is concluded that there is significant difference between mean ranks towards Importance to the Bank based internal components that contribute to NPA.This shows the validity of ranking based on mean.

- From Table 7.4, By Friedman Test it is concluded that there is significant difference between mean ranks towards Importance to the Bank based external components that contribute to NPA. This shows the validity of ranking based on mean.

8. Conclusion

This paper reveals the NPA and its scenario in all the scheduled commercial banks during the decade. It even depicts the various reasons for the growth of NPA. NPAs reflect the overall performance of the banks. A high level of NPA is a poor indicator of bank performance. The NPA growth involves the necessity of provisions, which reduces the overall profits and shareholders' value. Careful steps by the bankers like selection of right borrowers, viable economic activity correct end use of funds and timely recovery of loans are absolutely necessary pre conditions for preventing or reducing the incidence of new NPAs which will enhance the credibility of the banks and attain the objective of the sound financial system.

References

Ammannaya, K.K. (2004), “Indian Banking: 2010”, IBA Bulletin, 156.

Baiju, S. and Tharril, G.S. (2000), "Performance Banks with Non-performing Assets: An Analysis of NPAs, Yojna, 5-9.

Chaitanya V Krishna (2004). Causes of Non-performing Assets in Public Sector Banks. Economic Research, 17(1): 16-30.

Dash, MK., \&Kabra, G. (2010). The Determinants of Non-Performing Assets in Indian Commercial Banks: an Econometric Study, Middle Eastern Finance and Economics, 7.

Kaviths N (2012), "NPAs of Scheduled Commercial Banks in India- A Case Analysis”, Global Journal of Arts and Management.

Naveenan,RV\&Vijayakumar,T(2014):’NPA -A Humangous Burdenon Bank's Shoulders”,Asia Pacific Journal of Marketing \& Management Review,3(5),7-16.

Rajaraman, I \&Vashistha, G (2002): "Non-Performing Loans of Indian Public Sector Banks -Some Panel Results"e, Economic \& Political Weekly

Satpathy and Patnaik, (2012), "Portfolio of NPA- By Classification of Banks". BVMIR Management Edge.

Naveenan,RV,"Warning Signals - A Tool to Control NPA in Banks", International Journal of Advance Research in Computer Science and Management Studies,4(7), 280-288.

Naveenan,R.V.2016.A Study on Handling Non-Performing Assets with Special Reference to Public Sector Banks in Kanyakumari District(PhD Thesis).Manonmaniam Sundaranar University, Tirunelveli,Tamil Nadu, India.

\section{Copyrights}

Copyright for this article is retained by the author(s), with first publication rights granted to the journal.

This is an open-access article distributed under the terms and conditions of the Creative Commons Attribution license (http://creativecommons.org/licenses/by/4.0/). 